\title{
Nursing Education Research with a Focus on Clinical Simulation and Interprofessional Education / Recherche en formation infirmière axée sur la simulation clinique et la formation interprofessionnelle
}

Jacinthe I. Pepin

Université de Montréal, jacinthe.pepin@umontreal.ca

Florence Myrick

amyrick@ualberta.ca

Follow this and additional works at: https://qane-afi.casn.ca/journal

Part of the Nursing Commons

\section{Recommended Citation}

Pepin, Jacinthe I. and Myrick, Florence (2021) "Nursing Education Research with a Focus on Clinical Simulation and Interprofessional Education / Recherche en formation infirmière axée sur la simulation clinique et la formation interprofessionnelle," Quality Advancement in Nursing Education - Avancées en formation infirmière: Vol. 7: Iss. 1, Article 8.

DOI: https://doi.org/10.17483/2368-6669.1304

This Interview is brought to you for free and open access by Quality Advancement in Nursing Education - Avancées en formation infirmière. It has been accepted for inclusion in Quality Advancement in Nursing Education - Avancées en formation infirmière by an authorized editor of Quality Advancement in Nursing Education - Avancées en formation infirmière. 


\section{Nursing Education Research with a Focus on Clinical Simulation and Interprofessional Education}

Interviewee: Dr. Marian Luctkar-Flude, PhD, RN, CCSNE, the 2019 CASN Pat Griffin Scholar

Interviewer: Dr. Jacinthe Pepin, CoEditor-in Chief

Dr. Pepin: On behalf of Dr. Florence Myrick, Co-Editor-in-Chief, and myself, thank you, Dr. Luctkar-Flude, for agreeing to participate in this interview. I would like to begin our interview by asking if you could share with the readers your perspective on clinical simulation and its implications for quality nursing education and practice.

Dr. Luctkar-Flude: That is a very good question. You may or may not know that I have been engaging in clinical simulation for 15 years, all of it at Queen's University. We received funding from the Government of Ontario to purchase simulation equipment. The problem was there were not any guidelines on how to use simulation at the time and the training that we received was all provided by the vendors of the simulators. It is important to know that simulation is not only the technology; it is a teaching technique. It is very broad, and we have been using low-fidelity simulation for a long time. For example, when I was a nursing student, we practiced giving injections on oranges - that is a simulation. Clinical simulation where we participate in scenarios started in our program about 15 years ago, and so it has come a long way.

Initially, as I said, we did not have guidelines. We did a lot of simulations off the top of our heads. We did have some scenarios that were provided by the vendors, but we had to adapt them because

\section{Recherche en formation infirmière axée sur la simulation clinique et la formation interprofessionnelle}

Invitée : $D^{r e}$ Marian Luctkar-Flude, inf., PhD CCSNE, récipiendaire du prix de recherche en formation infirmière Pat Griffin de l'ACÉSI en 2019

Intervieweuse : $D^{r e}$ Jacinthe Pepin, corédactrice en chef

$D^{\text {re }}$ Pepin : En mon nom et au nom de la $\mathrm{D}^{\text {re }}$ Florence Myrick, co-rédactrice en chef, nous vous remercions de nous avoir accordé cet entretien. Pour commencer, pouvez-vous partager vos réflexions sur la simulation clinique et son impact sur la qualité de la formation et de la pratique infirmières?

$D^{\text {re }}$ Luctkar-Flude : Excellente question. Je ne sais pas si vous savez, mais je suis active dans le monde de la simulation clinique depuis déjà 15 ans, à Queen's University. Nous avons reçu des fonds du Gouvernement de l'Ontario pour l'achat de matériel de simulation. Le problème, c'est qu'il n'y avait pas de lignes directrices portant sur la simulation à l'époque. Donc, toutes les formations étaient données par les fournisseurs de simulateurs. Il importe de réaliser que lorsqu'on parle de simulation, il n'est pas seulement question d'une technologie, mais également d'une méthode d'enseignement. La simulation est un terme englobant et nous avons utilisé la simulation de basse fidélité depuis longtemps. Lorsque j'étais étudiante en sciences infirmières, par exemple, nous utilisions des oranges pour pratiquer nos techniques d'injection; il s'agit d'une simulation. Notre programme comprend, depuis environ 15 ans, des simulations cliniques incorporant des scénarios; nous avons donc parcouru beaucoup de chemin..

Comme je disais, au départ, nous n'avions pas de lignes directrices. Plusieurs de nos simulations étaient improvisées. Les scénarios 
they were not Canadian. We had to make sure they met our clinical guidelines and that we were using appropriate drugs and lab values because sometimes things are different in Canada and in the United States. Now, we have standards of best practice for simulation, and these were published by the International Nursing Association for Clinical Simulation and Learning [INACSL] (2016). There have been several versions of these guidelines, based on the years of research and the experience of using simulation to promote evidenceinformed simulation.

One of the key factors that emerged from these guidelines is that the quality of the education is really going to depend on the quality of the simulation. If you are merely throwing together a scenario without any thought, the quality of the education is going to suffer. Now, we are really stressing that we need quality in the design of the scenario, taking into consideration what the learning outcomes are and ensuring that the scenario aligns with the learning outcome. We have had problems in the past with instructors throwing something in to make the scenario more exciting, but if it did not align with the learning outcomes and the students were not expecting it, then it was not appropriate. We should not be throwing in new things for which they have not been prepared. We also have to think about aligning it to the level of the learner - a novice student versus a senior student: we have to consider how much simulation experience they have had, how much clinical experience they have had, and what is the appropriate level of simulation. Again, throwing in distractors is fine when you have senior students who know their clinical material well and who have engaged in a lot of simulation, but with a novice it is just going to send them down the wrong track. Purposefully designing the auxquels nous avions accès devaient être adaptés, car ils provenaient des fournisseurs et étaient créés en dehors du contexte canadien. Nous devions nous assurer qu'ils correspondaient à nos lignes directrices dans les domaines cliniques et qu'ils faisaient référence aux bons médicaments et aux bonnes valeurs de laboratoire, car il arrive que ces données soient différentes au Canada et aux États-Unis. Nous avons aujourd'hui des normes de pratiques exemplaires en matière de simulation, publiées par l'International Nursing Association for Clinical Simulation and Learning [INACSL] (2016). Plusieurs versions de ces lignes directrices se sont succédées suivant des années de recherche et d'expérience acquise, pour favoriser ainsi la simulation fondée sur les résultats probants.

Ces lignes directrices ont permis de discerner un facteur clé, soit que la qualité de la formation dépend de la qualité des simulations. Si vous inventez un scénario sans vraiment y penser, la qualité de la formation va en souffrir. Nous insistons maintenant beaucoup sur le besoin de qualité dans la conception des scénarios, en tenant compte des apprentissages visés et en nous assurant que les scénarios sont alignés aux résultats d'apprentissage. Nous avons rencontré des problèmes quand des enseignantes ajoutaient des éléments à un scénario pour le rendre plus excitant. Si ces nouveaux éléments n'étaient pas alignés avec les résultats d'apprentissage et que les étudiantes ne s'y attendaient pas, cela n'était pas pertinent. Nous ne devons pas ajouter des éléments pour lesquels les étudiantes ne sont pas prêtes. Il faut aussi considérer le niveau de l'apprenante, soit une apprenante novice ou une apprenante finissante. Nous devons tenir compte de leur expérience avec la simulation, de leur expérience en milieu clinique et du niveau de simulation qui s'avère le plus adéquat. Il convient d'ajouter des distracteurs pour des étudiantes plus avancées qui connaissent bien leur matériel clinique et qui 
simulation and facilitating it really relies on having simulation facilitated by educators who have been formally prepared. They need preparation on how to facilitate and how to debrief.

Debriefing is the part of simulation during which most of the learning often occurs because that is where everything that has occurred in the scenario is unpacked. You unpack the misconceptions that students have had and clarify issues for them. If you have a facilitator who just says, "Oh, that was great...," the students are not going to take much away from that experience, particularly if things went wrong and they were not clarified. That is a problem. The good news is that we do not really have an excuse now because we do have many faculty development opportunities so that educators can learn to design and facilitate simulation. As such, I was very excited when the Canadian Association of Schools of Nursing (CASN) proposed the Canadian Certified Simulation Nurse Educator Exam (CCSNE). I was involved in developing the online program to help prepare nurse educators to write the CCSNE exam, and I am one of the educators in the program as well. We now have over 30 CCSNEs in Canada, and that number is growing. There are between 30 and 40 participants in each class.People really want this education so they can provide good quality simulation.

Dr. Pepin: Can you tell us a little bit more about the importance of quality debriefing being part of the simulation.

Dr. Luctkar-Flude: So, you can have an unstructured debrief or a structured debrief, and there are numerous models out there with regard to how you can debrief. One of the common ones that is used is PEARLS (Promoting Excellence and Reflective Learning in Simulation), and there is also ont participé à plusieurs simulations, mais cette approche risque de déstabiliser les novices, qui pourraient alors faire fausse route. La conception intentionnelle d'une simulation et son animation doivent incomber à des enseignantes qui ont reçu une formation. Elles doivent se préparer à animer la simulation et le débriefing.

Le débriefing est la partie de la simulation où la majorité de l'apprentissage a lieu car il s'agit de comprendre ce qui s'est passé pendant le scénario. On peut alors décortiquer les incompréhensions des étudiantes et clarifier certains points avec elles. Si l'enseignante dit seulement «C'était superbe... », les étudiantes ne tireront rien de leur expérience, surtout si elles ont rencontré des difficultés qui sont demeurées sans explication. C'est un problème. La bonne nouvelle, c'est que nous n'avons plus d'excuse maintenant, car il existe beaucoup d'occasions de formation pour les membres du corps professoral, occasions qui permettent aux enseignantes d'apprendre à créer et à animer des simulations. J'étais très enthousiaste lorsque l'Association canadienne des écoles de sciences infirmières (l'ACESI) a proposé un examen de certification en simulation pour les infirmières enseignantes canadiennes (CCSNE). J'ai participé au développement du programme en ligne pour aider les enseignantes en sciences infirmières à se préparer pour cet examen. Nous comptons maintenant plus de 30 enseignantes détenant la certification au Canada et ce nombre ne cesse d'augmenter. Il y a entre 30 et 40 participantes par session, une indication que les enseignantes souhaitent vraiment se former pour offrir des simulations de qualité.

$D^{\text {re }}$ Pepin : Pouvez-vous nous en dire plus sur l'importance d'un débriefing de qualité lors des simulations ?

$D^{\text {re }}$ Luctkar-Flude : Les débriefings peuvent être structurés ou non structurés. Bien qu'il 
the G.A.S (Gather, Analysis, Summarize) method and Plus/Delta. The point is to provide a framework, to make sure the facilitators know how to use it, and to ensure that they practice its use before they facilitate with students because it is challenging, particularly if you have students who do not speak up. Debrief, yes, involves feedback, but it also involves a lot more self-reflection and drawing it out of students. It is not just the instructor saying, "You did this wrong; you did this wrong; you did this wrong." You want them to reflect on what they did well, how they felt, and how they might improve in the future. It is a type of an art to be able to do that well, so it is important to provide some education about that process. We can have the same simulation facilitated by a different instructor where one debrief only lasts 10 minutes and another one lasts 30 minutes In other words, it is related primarily to the skill of the instructor. It is important that we allot sufficient time for the debrief so that such issues can be explored.

Returning to the original question about the implications for quality nursing education and practice, there is now a growing body of evidence that supports the use of clinical simulation. There are a number of outcomes that have been measured - knowledge, confidence, critical thinking, and performance - and so, we have seen improvements in all of these outcomes in different studies. There are also numerous studies with regard to satisfaction. Generally, learners like simulation, again, as long as it is provided in a safe manner.

It is a little bit more challenging to demonstrate translation of simulation outcomes to practice, but there are recent studies in which this question is addressed. I think much of the evidence that I have, however, is still anecdotal. I will give you existe de nombreux modèles, celui surnommé PEARLS, qui vise à promouvoir l'excellence et l'apprentissage réflexif en simulation, est fréquemment utilisé. Il y a aussi la méthode G.A.S., qui signifie recueillir, analyser et résumer, et Plus/Delta. Le but est d'offrir un cadre et de s'assurer que les enseignantes savent comment l'utiliser et qu'elles se pratiquent avant d'effectuer l'animation auprès des étudiantes, car c'est difficile, particulièrement dans le cas d'étudiantes qui s'expriment peu. Le débriefing comprend, bien entendu, de la rétroaction, mais aussi beaucoup d'autoréflexion; il faut inciter les étudiantes à développer cette capacité. L'enseignante ne peut pas se contenter de dire « Tu as fait une erreur là, là et là ». Il est important que les étudiantes puissent réfléchir sur ce qu' elles ont bien fait, sur la manière dont elles se sont senties et sur ce qu'elles pourraient améliorer. Bien animer un débriefing est un art, il est donc important de fournir une formation adéquate. Le débriefing d'une même simulation animée par des enseignantes différentes peut prendre 10 minutes avec une et 30 minutes avec l'autre. Autrement dit, cela dépend principalement des compétences de l'enseignante. Il est important d'allouer suffisamment de temps au débriefing afin de pouvoir analyser les divers aspects de la situation simulée.

Si on revient à la question de départ quant aux implications de la simulation pour une formation et une pratique de qualité en sciences infirmières, de plus en plus de résultats probants appuient maintenant son utilisation. De nombreuses variables ont été mesurées (connaissances, confiance, pensée critique et performance), et différentes études ont permis d'observer des améliorations pour chacune d'elles. Il y a également plusieurs études portant sur la satisfaction. En général, les apprenantes aiment les simulations, tant qu'elles se déroulent de façon sécuritaire. 
an example. We had a postpartum hemorrhage scenario that was conducted interprofessionally with medical students and nursing students. A few weeks later, one of the students came back and told me that he had an opportunity to participate in the treatment of a postpartum hemorrhage in a clinical setting. He said that if he had not participated in the simulation, he would have just been standing back and watching because he would not have had a clue, but by participating in the simulation, he was confident and had the knowledge to go ahead and help in the situation. So, to me that is evidence that the simulation was a worthwhile experience for the preparation of the students. We also have had a number of cardiac resuscitation rounds as well where nursing students say, "Well, why do we have to learn the team leader role? We are not the leaders." Then, we have nurses out in practice who come back and tell us, "That was really important because I was the leader," and the nurse is the leader until the code team arrives, thus they need to know what to do and how to delegate. It is a beneficial way to practice before you are in the actual situation. I can tell you from my own personal experience that going through nursing education without simulation, my first code was not a good experience, and I really was lost. I think the students today are fortunate to have this opportunity. I think it makes sense to think of simulation as a bridge between the theory of nursing and clinical practice. You can teach students content with lectures and labs and readings, but the simulation actually provides them with the opportunity to apply that knowledge and those skills, ideally repeatedly, before they have to demonstrate those same competencies in the actual clinical setting. It is hopeful that by participating in the simulation, the students are less anxious, more confident, and more competent when they engage in clinical
Il est un peu plus difficile de démontrer la transposition dans la pratique, des apprentissages en simulation, mais des études récentes ont étudié la question. Cependant, la plupart des données sur le sujet sont anecdotiques. Je vous donne un exemple. Nous avions un scénario d'hémorragie postpartum réalisé en formation interprofessionnelle avec des étudiants en médecine et en sciences infirmières. Quelques semaines plus tard, un des étudiants est venu me voir pour me dire qu'il avait eu l'occasion de participer au traitement d'une hémorragie postpartum dans un contexte clinique. Il m'a dit que s'il n'avait pas préalablement participé à la simulation, il serait resté à l'écart pour observer, car il n'aurait pas su quoi faire. Mais comme il y avait participé, il était confiant et détenait suffisamment de connaissances pour s'impliquer. Cet exemple indique que l'expérience de simulation a un impact sur la préparation des étudiants. Nous effectuons aussi des séances de réanimation cardiaque au cours desquelles des étudiantes infirmières protestent parfois en disant : «Pourquoi doiton apprendre le rôle de chef d'équipe? Nous ne sommes pas les leaders ». Plus tard, des infirmières qui pratiquent reviennent nous dire : "C'était vraiment important comme expérience, car j'ai été la chef d'équipe ». Les infirmières sont en charge jusqu'à l'arrivée de l'équipe de code, elles doivent savoir quoi faire et comment déléguer. C'est une bonne façon de pratiquer avant de se trouver dans cette situation. Je peux vous dire, à partir de mon expérience personnelle, avec une formation infirmière sans simulation, que mon premier code n'a pas été une bonne expérience. Je me sentais vraiment perdue. Les étudiantes d'aujourd'hui sont chanceuses d'avoir cette possibilité. Il faut penser à la simulation comme étant un pont entre la théorie pertinente aux sciences infirmières et la pratique clinique. On peut enseigner la matière dans des cours magistraux, des laboratoires et à partir de lectures, mais la simulation offre aux 
practice compared to not having the simulation experience.

Dr. Pepin: The topic of interprofessional education (IPE) has become increasingly important in the new millennium. What role does simulation play in the quality of this education?

Dr. Luctkar-Flude: I think clinical simulation is ideally suited for interprofessional education because we traditionally teach our health professional learners in silos but then expect them to work together in teams in the clinical settings. I see that as being problematic. With simulation, we can bring the students from the different professions together to practice and collaborate and give them clinical cases which are relevant to all the learners; it is ideal for learning communication and teamwork. These skills are are so important for ensuring patient safety, as we know from research that it is usually communication breakdown that results in adverse events in the clinical setting during which patients are harmed. So, any opportunity to have students practice just talking to each other and learning about their roles is really important. And I cannot think of a better way to achieve it than through simulation.

Dr. Pepin: There are different degrees of simulation fidelity; it is not always about using technology. Can you expand on that issue?

Dr. Luctkar-Flude: Absolutely. I think the high-fidelity simulators are great when you are conducting a scenario that involves rapidly changing physiology. Cardiac resuscitation is a great example of where we would not want to be carrying out chest compressions on a real person, and we want to have those vital signs changing. But if you are completing a scenario, let us say a étudiantes une occasion d'utiliser ces connaissances et habiletés, idéalement plusieurs fois, avant d'avoir à les démontrer dans un contexte clinique. Nous espérons qu'après avoir participé aux simulations, les étudiantes seront moins anxieuses, plus confiantes et plus compétentes lorsqu'elles commenceront leur pratique clinique que si elles n'en avaient pas fait l'expérience.

$D^{\text {re }}$ Pepin : Le thème de la formation interprofessionnelle est devenu de plus en plus important dans le nouveau millénaire. Quel rôle joue la simulation dans la qualité de cette formation?

$D^{\text {re }}$ Luctkar-Flude : La simulation clinique convient parfaitement à la formation interprofessionnelle, car nos professionnels de la santé reçoivent traditionnellement une formation en vases clos, mais nous attendons d'eux qu'ils travaillent en équipe dans les milieux cliniques. C'est un problème. Avec la simulation, nous pouvons rassembler les étudiants de différentes professions pour pratiquer et travailler en équipe, et leur présenter des cas cliniques pertinents pour tous; c'est parfait pour apprendre la communication et le travail d'équipe. Ces compétences sont importantes pour assurer la sécurité des patients; nous savons grâce à des études qu'une mauvaise communication entraîne généralement des événements indésirables dans le contexte clinique, et ce sont les patients qui en subissent les conséquences. Toute occasion de permettre aux étudiants de pratiquer leur communication et d'apprendre leur rôle est importante. Je ne peux imaginer une meilleure façon d'y arriver qu'avec la simulation.

$D^{\text {re }}$ Pepin : Il y a différents degrés de fidélité en simulation; on n'utilise pas toujours la technologie. Pourriez-vous nous en parler davantage? 
palliative care scenario, for which we do not need a mannequin; having an actor or a standardized patient play the role of the patient creates more emotion, more realism, and it is more effective in that particular situation. It is like any other teaching tool where you have to weigh the benefits of the different types for the specific scenario and the specific learning outcomes. I find myself leaning more towards standardized patients in many scenarios, especially in the interprofessional context where we are talking about communication. But if you are completing a teamwork, like an Operating Room scenario, or that type of scenario, then having a mannequin is more appropriate because you can change the patient's condition and have the team react to the situation.

Dr. Pepin: So, clinical simulation plays an important part in the quality of the education as far as interprofessional education.

\section{Dr. Luctkar-Flude: I think so.}

Dr. Pepin: What do you foresee for the future of interprofessional education from your point of view?

Dr. Luctkar-Flude: I would like to see more for all of the reasons I just mentioned, such as helping to break down those barriers between the professions and assisting everyone in clarifying their roles to each other. However, the process is a challenging one because it requires considerable resources, and the different schools are on different schedules. It is really challenging to find the time to bring them together, let alone to create the scenarios and deliver them. I think we need to consider some more creative ways of delivering simulation. One of the areas that I have moved into is virtual simulation. This
D ${ }^{\text {re }}$ Luctkar-Flude : Absolument. Les simulateurs haute-fidélité conviennent aux scénarios dans lesquels les paramètres physiologiques changent rapidement. La réanimation cardiaque est un bon exemple: nous ne pouvons pas pratiquer les compressions thoraciques sur une vraie personne et nous désirons observer les changements dans les signes vitaux. Par contre, si nous planifions un scénario de soins palliatifs, par exemple, dans lequel nous n'avons pas besoin d'un mannequin, le fait d'avoir un acteur ou un patient simulé qui joue le rôle du patient crée davantage d'émotions et de réalisme, et c'est plus efficace pour ce genre de situation. C'est comme avec n'importe quel autre outil d'apprentissage : il faut mesurer les avantages pour les différents types de scénarios et les résultats d'apprentissage spécifiques. J'ai tendance à préférer les patients simulés pour de nombreuses situations, surtout dans un contexte interprofessionnel, lorsque nous parlons de communication. Cependant, s'il faut faire un travail d'équipe, par exemple dans un scénario de salle d'opération, l'utilisation d'un mannequin est plus appropriée, car il est possible de changer l'état du patient et de voir la réaction de l'équipe par rapport à la situation.

$D^{\text {re }}$ Pepin : Vous dites donc que la simulation joue un rôle important dans la qualité de l'enseignement quand on parle de formation interprofessionnelle.

$D^{\text {re }}$ Luctkar-Flude : Je crois que oui.

$D^{\text {re }}$ Pepin : Qu'est-ce que vous envisagez pour le futur de la formation interprofessionnelle?

$D^{\text {re }}$ Luctkar-Flude : Pour toutes les raisons que je viens d'énoncer, j'aimerais en voir davantage. Cette formation peut aider à briser les barrières entre les différentes professions et aider chacun à clarifier son rôle par rapport aux 
approach provides an opportunity where we could provide a number of interprofessional virtual simulations in which students could engage on their own time and then bring them together for a live simulation during which they can then apply all of the lessons they have learned by playing these virtual games. That is one way, I think, to help provide them more simulation without increasing the cost or the time factor.

Dr. Pepin: Would the in situ simulation be one of the appropriate ways to provide the interprofessional simulation, and does that always go with high-fidelity, or are there other possibilities in that direction?

Dr. Luctkar-Flude: That is a great question. In the hospital, in situ simulation is ideal because the nurses and doctors and other health professionals do not have much time to go off to a simulation lab to practice scenarios. By bringing the simulation to the health care providers, it makes it more accessible for them. The other advantage is they are already in a team, and so you are having the team members practice the simulation together. Thus, you can deliver it quickly. You might have 30 minutes in which to provide it, or you might even have something shorter, just brief refreshers here and there. Again, it depends on the nature of the scenario to decide whether you are going to use a high-fidelity mannequin or a standardized patient. If you are focusing on cardiopulmonary resuscitation (CPR), you are going to need a mannequin. On the other hand, if you are focusing on something such as de-escalation of an angry patient, having an actor would be more effective. I see both as being important.

Dr. Pepin: And again, you use the various types of simulations. I use the word types, autres. Cependant, le processus pose un défi, car il demande beaucoup de ressources, et les programmes ont des horaires différents. Il est difficile de trouver le temps de rassembler tout le monde, et encore plus de créer et de présenter les scénarios. Nous devons trouver des façons plus créatives de présenter les simulations. J'ai commencé à m'intéresser à la simulation virtuelle. Cette approche permet de présenter plusieurs simulations interprofessionnelles dans lesquelles les étudiants peuvent participer selon leur horaire, puis on les regroupe pour une simulation en direct durant laquelle ils peuvent appliquer toutes les leçons apprises avec les jeux virtuels. C'est une façon de leur offrir plus de simulations sans qu'ils aient à investir davantage d'argent ou de temps.

$D^{\text {re }}$ Pepin : La simulation in situ ne serait-elle pas appropriée pour la formation interprofessionnelle? Est-elle toujours de haute-fidélité ou y a-t-il d'autres possibilités dans la même veine?

$D^{\text {re }}$ Luctkar-Flude : C'est une bonne question. Dans le milieu hospitalier, ce genre de simulation est idéal, car les infirmières, les médecins et les autres professionnels de la santé n'ont pas beaucoup de temps pour se rendre dans un centre de simulation afin de participer à des scénarios. En rapprochant la simulation des professionnels de la santé, elle leur devient plus accessible. L'autre aspect positif est que ces professionnels font déjà partie d'une équipe et ils peuvent donc pratiquer ensemble leurs interventions. On peut alors effectuer la simulation dans un court temps. On peut avoir seulement 30 minutes pour une simulation, parfois même moins, pour des mises à jour ponctuelles. Encore une fois, l'utilisation d'un mannequin de hautefidélité ou d'un patient simulé dépend de la situation. Si elle porte sur la réanimation cardio-respiratoire, vous avez besoin d'un mannequin. Cependant, si vous travaillez sur la 
but there is a variety of tools to provide the simulations.

Dr. Luctkar-Flude: Yes, and we usually call those typologies or modalities so different modalities of simulation.

Dr. Pepin: Thank you. Could you share some of your research results that could have an important influence on the practice of nursing and inter-professional education?

Dr. Luctkar-Flude: Absolutely. Because simulation was new when we started, it was important that we engage in research as we implemented different types of simulation and in different courses. That was really a focus of mine all along. We first introduced simulation into the health assessment course, so I did do a study comparing the use of the high-fidelity simulator to standardized patients and community volunteers, the other modalities we were already using. It was interesting because the students preferred the standardized patient, and the reason they gave was that they were more realistic. They performed better with the simulators, however, and suggested that it was because of lower stress interacting with the mannequins. With the real patient, because it felt more real, they were more worried about their performance, so that was an interesting finding initially.

I was fortunate because my director at the time was Dr. Cynthia Baker who is now the Executive Director at CASN, and she had acquired a huge grant from, I believe, the Ministry of Health and Long-Term Care to develop an interprofessional education simulation curriculum. Since I was the simulation lab coordinator part-time, I was able to assume the coordinator role for this research project also on a part-time basis. Over the course of three years, we developed four different modules for interprofessional education (IPE). We désescalade d'un patient en colère, un acteur serait plus efficace. Les deux options sont importantes.

$D^{\text {re }}$ Pepin : Encore une fois, il faut se tourner vers différents types de simulation. Et ici, j'utilise «types », mais il faut penser que les simulations peuvent être effectuées avec diverses ressources.

$D^{\text {re }}$ Luctkar-Flude : Oui, et nous les appelons «types» ou «modalités », alors différentes modalités de simulation.

$D^{\text {re }}$ Pepin : Merci. Pourriez-vous partager certains résultats de vos recherches qui pourraient avoir une influence sur la pratique des sciences infirmières et la formation interprofessionnelle?

$D^{\text {re }}$ Luctkar-Flude : Absolument. Comme la simulation était une nouveauté quand nous avons commencé à l'utiliser, il était important de nous impliquer en recherche dans la mise en œuvre de différents types de simulation et dans différents cours. Cette implication a toujours été ma priorité. Nous avons d'abord introduit des simulations dans le cours d'évaluation de la santé; j'ai mené une étude qui comparait l'utilisation d'un mannequin haute-fidélité avec celle d'un patient simulé et de bénévoles, qui sont les modalités que nous utilisions déjà. C'était intéressant, car les étudiantes préféraient le patient simulé parce qu'il était plus réaliste. Cependant, elles ont obtenu de meilleurs résultats avec les mannequins. Selon elles, c'est parce qu'elles étaient moins stressées lorsqu'elles interagissaient avec un mannequin. Comme le vrai patient est réel, elles sont plus nerveuses pour bien performer. C'était une première découverte intéressante.

J'étais privilégiée, car ma directrice de l'époque était la $\mathrm{D}^{\text {re }}$ Cynthia Baker, qui est maintenant la directrice générale de l'ACÉSI. Elle venait d'obtenir une importante 
began with suctioning skills for nursing and physiotherapy students; we focused on cardiac resuscitation skills for nursing and medical students; and we focused on obstetrical and pediatric skills for nursing and medicine. Then we wanted to develop a simulation that would bring the three schools together, so we decided on infection control skills as a focus as all health professionals need to possess those skills particularly in today's times. One of the facts we learned from that particular study was that the students always focus on the clinical. The purpose of our learning outcomes was related to infection control and communication, but they were always focused on the clinical scenario that we gave them because they were anxious about not performing the clinical aspect well. We had to revamp how we prepared students for that particular scenario. We actually gave them the scenario ahead of time. We did this because we did not want them worried about the clinical skills so much as the other aspects, which was interesting. Overall, we learned that the simulation was a successful way to deliver IPE, and we used both qualitative and quantitative measures to determine that fact. All those modules are still provided in our program. We have this IPE curriculum that is ongoing.

Dr. Pepin: That is great. You mentioned the fact that sometimes the students are less stressed to work in simulated contexts as compared to when working with an actual patient. At the same time, we do read in some research results that anxiety could be very high during simulation. How could we go about reducing the anxiety that students experience?

Dr. Luctkar-Flude: I agree that students are anxious going into simulation and much of that anxiety will depend on how well they are prepared. We know, for example, that subvention du Ministère de la Santé et des Soins de longue durée afin de concevoir un programme de simulation pour la formation interprofessionnelle. Comme j'étais coordonnatrice du laboratoire de simulation à temps partiel, j'ai pu prendre le rôle de coordonnatrice de ce projet de recherche, également à temps partiel. Sur une période de trois ans, nous avons conçu quatre modules de formation interprofessionnelle. Nous avons commencé avec les habiletés d'aspiration pour les étudiants en sciences infirmière et en physiothérapie, de réanimation cardiaque pour les étudiants en sciences infirmières et en médecine, et celles liées à l'obstétrique et à la pédiatrie aussi pour les étudiants en sciences infirmières et en médecine. Nous voulions ensuite concevoir une simulation qui regrouperait les trois écoles, nous avons donc choisi les habiletés liées au contrôle des infections, que tous les professionnels de la santé doivent détenir, surtout en ce moment. Ce que nous avons appris par l'étude de ce scénario est que les étudiants se concentrent toujours sur l'aspect clinique. Les apprentissages visés portaient sur le contrôle des infections et la communication, mais les étudiants se concentraient plutôt sur l'aspect clinique du scénario que nous leur avions donné, car ils s'inquiétaient de ne pas bien le réussir. Nous avons dû revoir notre façon de préparer les étudiants pour ce scénario. Nous leur avons donc donné le scénario à l'avance afin qu'ils puissent se concentrer également sur les autres aspects, ce qui était intéressant. En général, nous avons appris que la simulation était une bonne façon d'offrir la formation interprofessionnelle, et nous avons utilisé des mesures qualitative et quantitative pour arriver à ce résultat. Le programme de formation interprofessionnelle comprend toujours ces modules.

$D^{\text {re }}$ Pepin : C'est bien. Vous avez mentionné que les étudiantes sont parfois moins stressées de travailler dans un contexte simulé qu'avec 
students do not always prepare for simulation because they are busy. If there are no marks assigned, they may choose not to prepare. So, we have done some work. We conducted a systematic review on presimulation preparation, and one of the factors we learned is that students prefer to engage in non-traditional methods of preparation. Traditional would involve lectures and readings versus non-traditional which would entail watching videos, playing a game, or doing something online. Since that time, we have completed some work in developing virtual simulation games as pre-simulation preparation. We received a grant through eCampusOntario. We developed four games and had four sites- Queen's University, Trent University, Nipissing University, and the University of Ottawa- and had faculty from each of those universities participate in the project. We each developed a game but then implemented two of the games at each site and measured outcomes comparing virtual simulation game preparation versus a case study. We did not find any differences between the two groups, but there were some limitations. One of the limitations was that we did not actually determine whether the student had completed the preparation for which they were assigned. I think that may have influenced the results.

Consequently, I conducted a follow-up study in which I gave the students both the game and the case study and all the traditional preparation. I then asked them to do whatever they wanted to prepare for the simulation. They had been provided the learning outcomes, so they knew what was expected of them in the simulation. Also, the case study and the game had the exact same questions, so it was the same content. I was surprised that more of the students completed the case study rather than the game, but those who completed the game un vrai patient. En même temps, certaines études soulignent que le niveau d'anxiété peut être très élevé pendant les simulations. Comment pouvons-nous diminuer l'anxiété des étudiantes?

$D^{\text {re }}$ Luctkar-Flude : Il est vrai que les étudiantes sont anxieuses quand elles arrivent en simulation et ce niveau d'anxiété dépend de leur préparation. Nous savons, par exemple, que les étudiantes sont parfois trop occupées pour se préparer aux exercices de simulation. $\mathrm{Si}$ ces exercices ne sont pas notés, il est possible qu'elles décident de ne pas s'y préparer; nous avons décidé d'y remédier. Nous avons mené une revue systématique des écrits sur la préparation pré-simulation, grâce à laquelle nous avons appris que les étudiantes préfèrent les méthodes de préparation non traditionnelles. Les méthodes traditionnelles comprennent les cours magistraux et les lectures, alors que les méthodes non traditionnelles consistent en des vidéos, des jeux ou des activités en ligne. Depuis ce temps, nous avons travaillé à la conception de jeux virtuels pour la préparation aux scénarios de simulation. Nous avons reçu une subvention du eCampusOntario qui nous a permis de créer quatre jeux avec la collaboration de membres du corps professoral de chacune des universités impliquées, soit la Queen's University, la Trent University, la Nipissing University et l'University of Ottawa. Chacune a développé un jeu et a mis en œuvre deux jeux. Nous avons mesuré les résultats de la préparation avec un jeu virtuel par rapport à une étude de cas. Nous n'avons pas trouvé de différence entre les deux groupes, mais nous avons observé certaines limites. Par exemple, nous avons été incapables de déterminer si les étudiantes avaient terminé la préparation qui leur était assignée, ce qui a pu influencer les résultats.

J'ai donc mené une étude de suivi dans laquelle j'ai remis aux étudiantes le jeu et l'étude de 
rated it higher than those who did the case study. Some of the qualitative feedback was interesting. They would say, "Oh, I like to read, so I did the case study" or "Oh, I am a visual learner, so I played the game." I think the lesson I learned from that feedback was that it is valuable to offer students a choice in how they prepare and then they might be more likely to do something. I found that to be an interesting result. I would like to repeat that study, however, because it was given to our students directly after they had returned from their final practicum. They may not have really thought about how they wanted to prepare and just did what was faster, which they might have thought was the case study. I would like to try it again and witness the results in a regular classroom setting rather than at the completion of the year. However, I still think it makes sense that some students will prefer one method over another.

Dr. Pepin: This is an interesting finding. And you feel that the level of anxiety for the students is reduced by letting them choose the kind of preparation?

Dr. Luctkar-Flude: Yes, and I think it is even more important in interprofessional education because, as I mentioned before, the anxiety is so high. It is bad enough to look ill prepared in front of members of your own profession, but they really do not want to look ill prepared in front of the other professions. And so, ensuring that they are well prepared is going to be very important.

Dr. Pepin: That is a good point. Thank you. What is your current research question and how could the Pat Griffin award that you received facilitate it?

Dr. Luctkar-Flude: Yes. I just made my decision that I am going to use the funding to support an ongoing project. This project cas, ainsi que la préparation traditionnelle. Je leur ai ensuite dit de se préparer à la simulation comme elles le voulaient. Elles connaissaient les apprentissages visés, elles savaient donc ce qu'on attendait d'elles dans la simulation. L'étude de cas et le jeu contenaient exactement les mêmes questions, alors le contenu était le même. J'ai été surprise de voir que plus d'étudiantes ont choisi l'étude de cas que le jeu, mais celles qui ont choisi le jeu lui ont accordé une meilleure évaluation que celles qui ont fait l'étude de cas. Certains des commentaires qualitatifs étaient également intéressants. Certaines ont dit : «J'aime lire, alors j'ai choisi l'étude de cas » ou encore : «Je suis visuelle, alors j'ai choisi le jeu». Nous en avons conclu que c'était une bonne idée d'offrir aux étudiantes un choix pour leur préparation, car les chances qu'elles le fassent sont alors plus grandes. J'ai trouvé ce résultat intéressant. Cependant, j' aimerais répéter cette étude, car elle a été menée tout de suite après leur dernier stage. Il est donc possible qu'elles n'aient pas vraiment pensé à la façon dont elles voulaient se préparer et aient simplement choisi ce qui était le plus rapide : l'étude de cas, en l'occurrence. J'aimerais bien répéter l'expérience, et observer les résultats en salle de classe plutôt qu'à la fin de l'année. Je crois toujours qu'il est logique que certaines étudiantes préfèrent une méthode plutôt qu'une autre.

$D^{\text {re }}$ Pepin : Ce résultat est intéressant. Croyezvous que le niveau d'anxiété des étudiantes diminue lorsqu'elles peuvent choisir leur méthode de préparation?

$D^{\text {re }}$ Luctkar-Flude : Oui, et c'est encore plus important pour la formation interprofessionnelle où, comme je l'ai mentionné plus tôt, le niveau d'anxiété est très élevé. Sembler mal préparée devant ses pairs est déjà assez désagréable, mais c'est encore pire devant d'autres professionnels. Il sera 
was originally funded by the Canadian Institute for Health Research (CIHR) to develop educational resources for nurses about cultural humility and providing health care for persons who identify as LGBTQI2S. It was a contract received by three graduate students from a CIHR grant as part of the CIHR Hacking the Knowledge Gap Series: The Trainee Award for Innovations Thinking to Support LGBTQI2S Health and Wellness $(\$ 60,000)$. We have created the SOGI Nursing Educational Toolkit. SOGI stands for Sexual Orientation and Gender Identity. The website has a number of resources, including links to resources, PDFs of resources, and video lectures by some experts in the field (which are brief-mini lectures). ${ }^{1}$ We just have some key content to share with them, and we also have some virtual simulation games. We have created four games. Our team consisted of three LGBTQI2S experts and three simulation experts, so we created these four games that are based on authentic cases of LGBTQI2S persons interacting in the health care setting and some of the challenges they have encountered. The game allows the student to be in the shoes of the nurse, so it is a game filmed from the perspective of the nurse. The student will see the patient react to what the nurse is saying. They are then given a series of questions- what should the nurse do next, what should the nurse say next- and if they select an incorrect or "not the best" answer, they observe how it plays out and they see how the patient looks (if the patient looks angry or if the patient looks sad etc.). Then, the rationale pops up to tell them why that was a good or not so good choice. They can then go back and select again until they arrive at the correct or best answer. We filmed the games in English and in French. The whole website is mostly English, but donc très important d'assurer qu'elles soient bien préparées.

$D^{\text {re }}$ Pepin : Effectivement. Merci. Sur quoi travaillez-vous actuellement, et comment le prix Pat Griffin que vous avez reçu peut-il vous aider?

$D^{\text {re }}$ Luctkar-Flude : Oui. J'ai décidé d'utiliser cette subvention pour soutenir un projet en cours. Le projet a d'abord été financé par l'Institut de recherche en santé du Canada afin de concevoir des ressources éducatives pour les infirmières sur l'humilité culturelle et les soins aux personnes qui s'identifient comme LGBTQI2S. Un contrat avait été donné à trois étudiantes des cycles supérieurs à l'aide d'une subvention de l'Institut dans le cadre de la série «Combler les lacunes dans la recherche en santé »: bourse de formation «Pensée innovatrice au service de la santé et du bienêtre des personnes LGBTQI2S » (60 $000 \$)$. Nous avons créé la boîte à outils SOGI (Sexual Orientation and Gender Identity) pour la formation en sciences infirmières sur le thème orientation sexuelle et identité de genre. Le site Web contient de nombreuses ressources, incluant des liens vers des ressources, des documents en format PDF et de courtes capsules vidéo d'experts dans le domaine ${ }^{1}$. Nous avons partagé du contenu essentiel ainsi que des jeux de simulation virtuels. Notre équipe était composée de trois experts LGBTQI2S et trois experts en simulation. Nous avons créé quatre jeux inspirés de cas authentiques de personnes LGBTQI2S qui interagissent dans un contexte de soins de santé, et certains des défis auxquels elles ont fait face. Le jeu permet aux étudiantes de se mettre dans la peau de l'infirmière, car le jeu est filmé du point de vue de cette dernière. Les étudiantes voient les réactions du patient par rapport à ce que dit l'infirmière. Des questions sont posées (que devrait faire l'infirmière

\footnotetext{
${ }^{1}$ The website can be found here: https://www.soginursing.ca/

${ }^{1}$ Le site Web se trouve à l'adresse suivante : https://www.soginursing.ca/ (en anglais seulement).
} 
we did want to provide some French resources, so we will present the four games in French. We also display a few mini games that are just one or two decision points as well with resources that are aligned with each of the games. We also pose self-reflections and quizzes, which help support learning for students or nurses or educators or even other health professionals.

The website was launched in the Fall of 2020, but the funding is coming to an end. That is the reason why I thought I would use the Pat Griffin funding to carry out an evaluation of the toolkit. Some of the outcomes I will probably investigate are the feasibility of using this toolkit in the classroom, or its use by nurses or whomever; examining the usability of the entire module; and considering the learning outcomes associated with completing the module. I am probably going to use a mixed methods study design. I will collaborate with my colleagues from the University of Ottawa and Ryerson University who are on the team and collect data from undergraduate and graduate students. I am interested in the graduate students because we have nurse practitioner students here at all three sites, so I think this research will be very valuable for them as well. This funding will support that evaluation.

Dr. Pepin: This is great. You called the domain concept cultural humility. Is that right?

Dr. Luctkar-Flude: Yes. That term is a step up from cultural competence because cultural competence implies that we are experts. How can we ever be an expert in someone else's experience? Cultural humility is a newer approach that is more authentic and gives the power to the ensuite, que devrait-elle dire) et si elles choisissent une réponse incorrecte ou une qui n'est pas la meilleure, elles peuvent observer ce qui arrive en voyant la réaction du patient (s'il a l'air fâché, triste, etc.). La justification apparaît ensuite à l'écran pour expliquer pourquoi la réponse était bonne ou moins bonne. Les étudiantes peuvent revenir en arrière et recommencer jusqu'à ce qu'elles obtiennent la bonne ou la meilleure réponse. Nous avons filmé les jeux en français et en anglais. Le site est principalement en anglais, mais nous voulions tout de même fournir des ressources dans les deux langues. Nous proposons également des mini-jeux qui demandent seulement une ou deux décisions, ainsi que les ressources en lien avec chacun d'eux. Nous offrons aussi des exercices d'autoréflexion et des questionnaires qui visent à faciliter l'apprentissage des étudiantes, des infirmières, des enseignantes et même d'autres professionnels de la santé.

Le site Web a été mis en ligne à l'automne 2020, mais le financement tire maintenant à sa fin. C'est pourquoi j'ai pensé utiliser le prix Pat Griffin afin d'évaluer la boîte à outils. Je souhaite examiner la faisabilité d'utiliser ces outils en classe, ou par des infirmières ou autres en milieux cliniques, la facilité d'utilisation du module et les retombées en termes d'apprentissages associés à la réalisation du module. Je vais probablement utiliser un devis méthodologique mixte. Je collaborerai avec mes collègues de l'Université d'Ottawa et de la Ryerson University et collecterai des données auprès d'étudiantes de premier cycle et des cycles supérieurs. Je m'intéresse aux étudiantes infirmières praticiennes car notre programme est offert aux trois emplacements et que cette recherche sera également précieuse pour elles. La subvention permettra de soutenir cette évaluation. 
individual, rather than to the health care professional.

Dr. Pepin: This is a great project. It is a great use, I would say, of the award. And I think it is interesting that this simulation is centred on the nurse-patient relationship.

Dr. Luctkar-Flude: Yes. It is something that is a gap right now in our curriculum, and we are becoming more aware of the health inequities associated with the LGBTQI2S community and their interactions with health care, or their lack of interactions, because of the stigma. The website is open-access and available across the country, so anyone will be able to use these resources.

Dr. Pepin: The last question we had was what do you see for the future of clinical simulation? How do you see it progressing? Is it similar to what you foresee for the future of interprofessional education?

Dr. Luctkar-Flude: I think that clinical simulation has really helped to move IPE forward in a positive way, and I really hope it continues to do so. As I mentioned before, there are restrictions of time and resources to support this type of learning as it is so resource intensive. I suggested earlier than virtual simulation games might provide a more accessible way to deliver simulation and having learners play a number of games before they participate in a team simulation might be a way to achieve it. Or you could have two or three interprofessional students, or a class, playing the game live together, making the decisions together. There is also the virtual reality. Most of it is single player but I believe there are multi-player games available or emerging, so you could have different learners from different professions in the same virtual world interacting. There are also the avatar-based types of games.
$D^{\text {re }}$ Pepin : Superbe. Vous avez mentionné que le concept était l'humilité culturelle. Est-ce que j'ai bien compris?

$D^{\text {re }}$ Luctkar-Flude : Oui. C'est une progression par rapport au concept de compétence culturelle, car à mon avis, ce dernier sous-entend que nous sommes des expertes. Comment pouvons-nous être expertes dans l'expérience d'une autre personne? L'humilité culturelle est une approche récente et plus authentique; elle donne le pouvoir à la personne plutôt qu'aux professionnels de la santé.

$D^{\text {re }}$ Pepin : Ce projet est admirable. Quelle excellente manière d'utiliser la bourse! Je crois aussi intéressant le fait que la simulation soit axée sur la relation infirmière-patient.

$D^{\text {re }}$ Luctkar-Flude : Oui. C'est une lacune en ce moment dans notre programme et nous devenons plus conscients des inégalités pour la communauté LGBTQI2S dans leurs interactions liées aux soins de santé, ou plutôt leur manque d'interaction, à cause de la stigmatisation. Le site Web est en accès libre partout au pays, alors n'importe qui ayant accès à Internet peut utiliser ces ressources.

Dre Pepin : Voici mes dernières questions : que voyez-vous pour l'avenir de la simulation clinique? Comment envisagez-vous sa progression? Est-ce que ça ressemble à ce que vous envisagez pour l'avenir de la formation interprofessionnelle?

$D^{\text {re }}$ Luctkar-Flude : La simulation clinique a réellement aidé à faire progresser la formation interprofessionnelle, et j'espère qu'elle continuera à le faire. Ce type d'apprentissage demande des ressources considérables en temps et en argent. J'ai suggéré plus tôt que les jeux de simulation virtuels pourraient être une façon plus accessible d'offrir des simulations; offrir aux apprenantes des jeux avant la 
Again, you can have different learners in the same setting in the virtual world interacting together. I do not know a lot about that type of simulation, but it is certainly an option. There are different associated expenses with that approach, but as technology advances the price tags decrease. Then, maybe some of these other, newer methods will be more accessible and would have implications for interprofessional education. I also think, similar with communication technology, having webinars online using for example Zoom, where people can see each other, you can actually bring together teams from different hospitals or different schools that are interprofessional and engage in discussions on any particular topic. That process would not be simulation per say, but it would be a different way to deliver interprofessional education that might be useful.

Dr. Pepin: So, using communication technology a little bit more. Is there anything else that we did not discuss that you would like to tell us about your field, or is there any message or any more topics that you would like to discuss?

Dr. Luctkar-Flude: Well, I think the message that I was endeavouring to communicate when I delivered my talk at the Pat Griffin Annual Lecture is the importance of collaborating. Our resources are becoming scarcer, so if you have something innovative, share it with others, collaborate, and we can all learn from each other. This is how my research program has grown. I participate in ongoing collaboration with Dr. Jane Tyerman from the University of Ottawa, and I have many connections through the Canadian Alliance of Nurse Educators using Simulation (CAN-Sim). The whole premise of that organization is to share resources with nurse educators across the country. We have some participation à une simulation d'équipe pourrait être une façon de contourner ces contraintes. On pourrait aussi inviter deux ou trois étudiants de différentes professions ou même une classe à participer ensemble au jeu et à prendre des décisions en équipe. Il y a également la réalité virtuelle. La plupart du temps, la simulation est faite pour une seule personne, mais je crois que des jeux virtuels multi-joueurs sont offerts ou vont l'être bientôt. Des apprenants de différentes professions pourraient donc interagir dans le même monde virtuel. Il y a aussi des jeux basés sur des avatars dans lesquels plusieurs étudiants d'un même milieu peuvent interagir dans le monde virtuel. Je ne connais pas beaucoup ces types de simulation, mais c'est assurément une option. Encore une fois, des dépenses sont associées à ces options, mais à mesure que la technologie progresse, le prix diminue. Il est possible que certaines de ces nouvelles méthodes seront plus accessibles et auront des retombées pour la formation interprofessionnelle. Utilisant les technologies des communications, des webinaires en ligne, via Zoom, par exemple, pourraient rassembler des équipes interprofessionnelles de différents hôpitaux ou différentes écoles afin de mener des discussions sur tout sujet. Ce processus n'est pas vraiment une simulation, mais il représente une autre façon utile d'offrir une formation interprofessionnelle.

$D^{\text {re }}$ Pepin : Vous parlez donc d'utiliser un peu plus les technologies des communications. Y a-t-il autre chose que vous aimeriez nous communiquer à propos de votre domaine, ou encore un message à partager?

$D^{\text {re }}$ Luctkar-Flude : Le message que je me suis engagée à partager lors de mon allocution à la Conférence annuelle Pat Griffin concerne l'importance de la collaboration. Les ressources se font de plus en plus rares, alors si vous avez des idées novatrices, partagez-les avec les autres, collaborez; nous pourrons ainsi 
great simulation resources there - we have scenarios, we have games, and I am always encouraging people to engage in research and to publish. If you do not publish, people cannot learn from what you have learned, so that is what I have been striving to do. I am a little behind, but that is what I have been doing every step of the way in my simulation career. I have been conducting a research study and publishing it or attending a conference and sharing it in that context so that we can build on each other's work and generate well-informed evidence to support the direction that we are proposing in our guidelines.

Dr. Pepin: I concur that it is crucial to share especially because simulation is a field that moves rapidly. The technology is changing rapidly, the modalities of simulation are expanding, so it is important to share the resources and share all that is learned by implementing learning modalities.

\section{Dr. Luctkar-Flude: Yes.}

Dr. Pepin: Well, thank you very much, Dr. Luctkar-Flude, for sharing your expertise with the QANE-AFI readers. You have covered a lot of ground.

Dr. Luctkar-Flude: You are very welcome. tous apprendre les uns des autres. C'est la façon dont mon programme de recherche a pu s'enrichir. Je collabore beaucoup avec la $\mathrm{D}^{\text {re }}$ Jane Tyerman de l'Université d'Ottawa et j'ai accès à un réseau élargi grâce à la Canadian Alliance of Nurse Educators using Simulation (CAN-Sim). Le but de l'organisation est de partager des ressources avec les infirmières enseignantes partout au pays. Le site héberge d'excellentes ressources en simulation, des scénarios et des jeux, et j'encourage toujours les personnes à mener des recherches et à publier des articles. Si vous ne publiez pas, les autres ne peuvent pas apprendre de vos recherches. J'ai pris un peu de retard, mais j'ai procédé ainsi à toutes les étapes de ma carrière en simulation : j'ai mené des études et j'en ai publié les résultats, ou j'ai assisté à des conférence pour les partager de sorte que nous puissions construire sur le travail des uns et des autres et générer des résultats probants visant à appuyer nos lignes directrices.

$D^{\text {re }}$ Pepin : Le partage est effectivement essentiel, surtout du fait que la simulation est un domaine qui évolue rapidement. La technologie change à grande vitesse, et les modalités de simulation se diversifient, alors il est important de partager les ressources et les apprentissages faits en mettant en œuvre des modalités d'apprentissage.

$D^{\text {re }}$ Luctkar-Flude : Oui.

$D^{\text {re }}$ Pepin : Merci infiniment d'avoir partagé votre expertise avec les lecteurs du QANE-AFI. Vous nous avez beaucoup appris.

D $^{\text {re }}$ Luctkar-Flude : Ça m'a fait plaisir. 
Quality Advancement in Nursing Education - Avancées en formation infirmière, Vol. 7, Iss. 1 [2021], Art. 8

\section{References/ Références}

International Nursing Association for Clinical Simulation and Learning. (2016). INACSL Standards of Best Practice: Simulation $\odot$. https://www.inacsl.org/inacsl-standards-of-bestpractice-simulation/ 